\title{
4. PALEOMAGNETIC INVESTIGATION OF THE IGNEOUS SEQUENCE, SITE 807, ONTONG JAVA PLATEAU, AND A DISCUSSION OF PACIFIC TRUE POLAR WANDER ${ }^{1}$
}

\author{
Helmut Mayer ${ }^{2}$ and John A. Tarduno ${ }^{2}$
}

\begin{abstract}
Characteristic remanent magnetizations derived from detailed thermal and alternating-field demagnetization of basalts recovered at Ocean Drilling Program (ODP) Site 807 on the Ontong Java Plateau reveal constant normal polarity consistent with paleontological ages from overlying sediments, suggesting deposition in early Aptian times at the beginning of the Cretaceous Normal Polarity Superchron (K-N). The paleomagnetic data can be divided into 14 distinct inclination groups, which together define a paleolatitude of $18^{\circ} \mathrm{S}$, some $16^{\circ}$ shallower than expected from a Pacific apparent polar wander path (APWP) based on nonsedimentary data. The data display a trend in paleomagnetic inclination, showing shallower values with increasing depth. We conclude that this trend is a result of local tectonic tilting during the waning phases of volcanism on the plateau. Hotspot-based plate reconstructions for the Early Cretaceous place the Ontong Java Plateau on the Louisville hotspot, presently located at $51^{\circ} \mathrm{S}$, whereas the paleolatitude for Site 807 based on the Pacific APWP is $34^{\circ} \mathrm{S}$. Because the nominal mean inclination from Site 807 and values derived from Deep Sea Drilling Project (DSDP) sediments of other sites predict shallower paleolatitudes for the Ontong Java Plateau, values from the Pacific APWP provide lower bounds on true polar wander. Considering mantle plume sources on the southern and northern portions of the plateau (DSDP Site 288 and ODP Site 807, respectively), the Louisville hotspot appears to have moved $9^{\circ}-17^{\circ}$ to the south relative to the spin axis since the Early Cretaceous. This sense of motion is consistent with previous results for the Suiko Seamount $(65 \mathrm{Ma})$ of the Hawaiian-Emperor Chain.
\end{abstract}

\section{INTRODUCTION}

The Ontong Java Plateau, arguably the largest oceanic plateau (Fig. 1), was drilled at Site 807 (Hole $807 \mathrm{C}: 3.6^{\circ} \mathrm{N}, 152.6^{\circ} \mathrm{E}$ ) with the objective of recovering cores from the basement to test various models for the origin of the plateau, including its paleolatitude during formation. Before Leg 130, the only other basement penetration on the Ontong Java Plateau was approximately $9 \mathrm{~m}$ by Deep Sea Drilling Project (DSDP) Leg 30 at Site 289. The sedimentary sequence above basement at Site 289 contains late Aptian limestone, overlying and interbedded with tuff (Andrews, Packham, et al., 1975), an overlying 80 -cm interval of reddish brown zeolitic claystone, in turn overlain by Maastrichtian-Campanian limestone. Ocean Drilling Program (ODP) Hole $807 \mathrm{C}$ is situated in a small basement graben and was so chosen to recover Cretaceous sediments not present at DSDP Site 289. It was hoped that this structure would trap the oldest sediments deposited on basalt that could be used to date the cessation of volcanism.

In terms of recovering Cretaceous sediments, the drilling strategy was a success as a sedimentary sequence remarkably similar to that recovered at Site 289 was recovered but greatly expanded. Maastrichtian-Campanian limestone overlies $18 \mathrm{~m}$ of reddish brown claystone, which in turn overlies approximately $10 \mathrm{~m}$ of limestone (Kroenke, Berger, Janecek, et al., 1991). The limestone directly overlies basement and contains foraminifers of the Globigerinelloides blowi Zone, indicating an early Aptian age ( $118 \mathrm{Ma}$, Harland et al., 1982; 121 Ma, Harland et al., 1990; see Tarduno et al., 1991, for discussion), at the beginning of the Cretaceous Normal Polarity Superchron $(\mathrm{K}-\mathrm{N})$.

Basement drilling at Site 807 penetrated $148.7 \mathrm{~m}$ of fresh, tholeiitic basalts consisting of both pillow and massive flows. The latter are mostly $<3 \mathrm{~m}$ thick but include one 28 -m-thick flow, comparable in thickness to flows in continental flood basalt provinces. Resistivity data from logging suggest that the hole was terminated at the top of another thick massive flow. The new age data from Site 807, together

\footnotetext{
'Berger, W.H., Kroenke, L.W., Mayer, L.A., et al., 1993. Proc. ODP, Sci. Results, 130: College Station, TX (Ocean Drilling Program).

${ }^{2}$ Geological Research Division, Scripps Institution of Oceanography, University of California, San Diego, La Jolla, CA 92093, U.S.A.
}

with stratigraphic columns from throughout the Pacific basin, have led Tarduno et al. (1991) to suggest that the Ontong Java Plateau formed rapidly ( $<3$ m.y.) by a broad mantle plume source (see Fig. 1).

The basement sequence can be divided into five volcanic subunits along with two sedimentary subunits represented by thin layers $(0.07-0.50 \mathrm{~m})$ of vitric tuff and limestone. The igneous stratigraphic sequence was divided as follows (Kroenke, Berger, Janecek, et al., 1991, pp. 452-453): Subunit A, 1379.7-1424.6 mbsf, plagioclasebearing pillow flows and thin massive flows, $>35$ cooling units; Subunit B, 1424.6-1425.1 mbsf, sedimentary interbed, limestone interbedded with vitric tuff; Subunit C, 1425.1-1441.9 mbsf, olivinebearing pillow flows, $>9$ cooling units; Subunit D, 1441.9-1442.0 mbsf, sediment interbed, limestone containing glauconite; Subunit E, 1442.0-1447.0 mbsf, thin massive flows, $>6$ cooling units; Subunit F, 1447.0-1475.0 mbsf, thick, massive, olivine-bearing flow, 1 cooling unit; Subunit G, 1475.0-1528.4 mbsf, olivine-bearing pillow flows and thin massive flows, $>34$ cooling units. Logging data suggest that a third interbed may be present, but it was not recovered (1435 m; Kroenke, Berger, Janecek, et al., 1991, p. 444). Downhole dip-meter measurements suggest that Hole $807 \mathrm{C}$ deviates no more than $1.5^{\circ}$ throughout the basement sequence.

In this paper we report a preliminary paleomagnetic analysis of the Hole $807 \mathrm{C}$ igneous sequence. Our analysis was conducted on shipboard paleomagnetic samples $(n=75)$, which were measured on a CTF 3-axis cryogenic magnetometer at Scripps Institution of Oceanography. Standard paleomagnetic minicores $(2.54 \mathrm{~cm})$ were collected on board. Veins and alteration rinds on pillows were avoided during sampling. Therefore, our collections should reflect the leastaltered portions of the igneous sequence.

\section{DEMAGNETIZATION DATA}

Stepwise demagnetizations were applied to all samples (i.e., no blanket demagnetizations were applied). Detailed stepwise thermal demagnetization was applied to 46 samples. Volume magnetic susceptibility $(K)$ was monitored during heating. Koenigsberger ratios $(Q)$ are uniformly greater than 1 (see Table 1 ). From the thermal demagnetization data, three types of directional behavior can be recognized. In Category A (Fig. 2), thermal demagnetization defines 


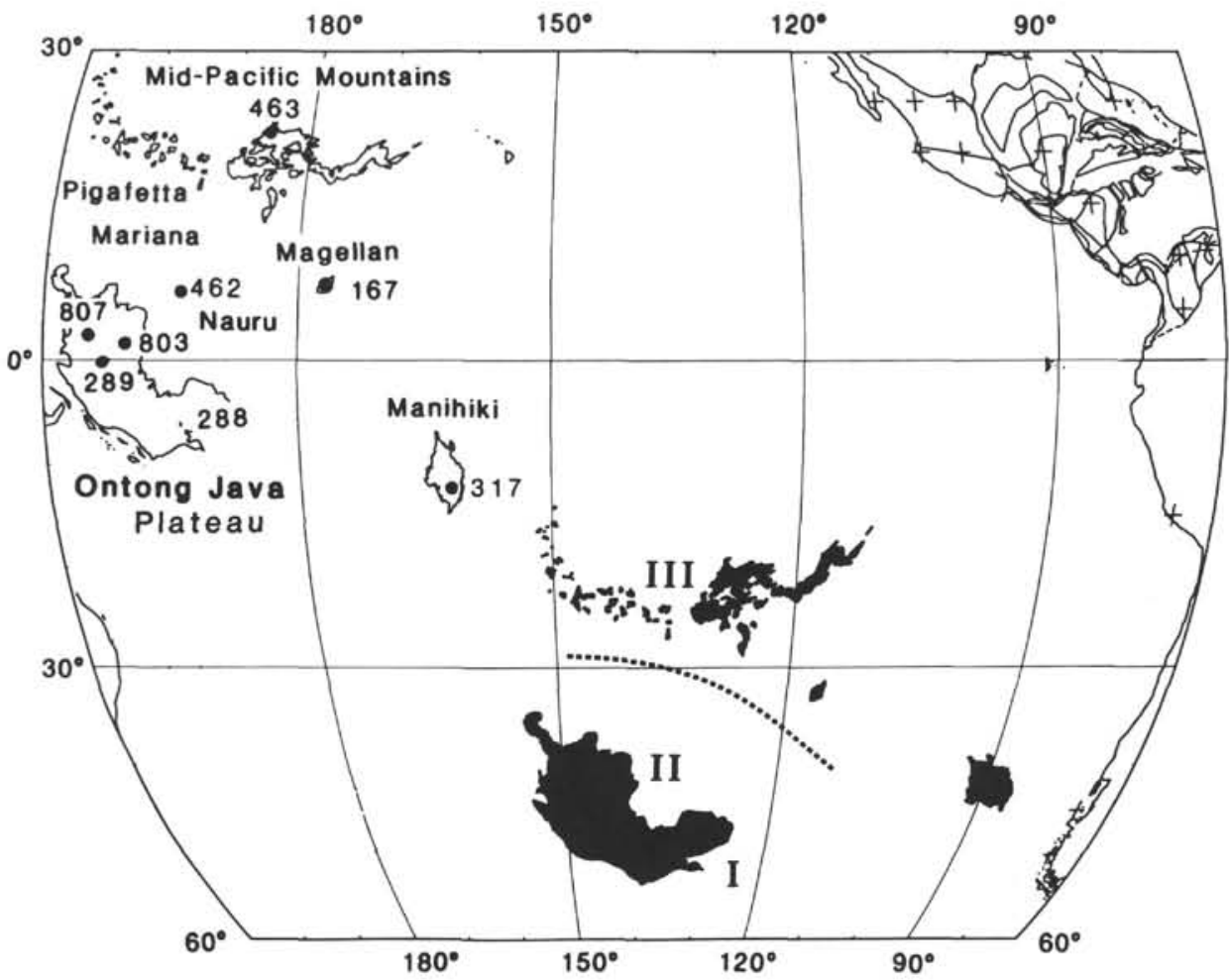

Figure 1. Location of Site 807 along with other relevant DSDP and ODP sites and bathymetric features in the area. Open outlines $=$ present-day positions; solid figures = reconstruction to $120 \mathrm{Ma}$ using a fixed hotspot rotation frame (Duncan and Clague, 1985). The Ontong Java Plateau is hypothesized to have formed from a broad plume source recorded in three zones surrounding the plateau. In Zone I, the plateau itself formed. In Zone II, fissures formed in areas of lithospheric weakness and Jurassic oceanic crust was capped by volcanic flows and intruded with sills (recorded at DSDP Site 462 and at sites from ODP Leg 129 in the Mariana and Pigafetta basins). In Zone III, volcanic debris is recorded in sedimentary columns atop bathymetric features formed before the Ontong Java Plateau (Mid-Pacific Mountains and Magellan Rise). Such debris may be a result of local seamount volcanism induced by the Ontong Java plume and exceptional eruptions on the plateau itself. Manihiki Plateau is coeval with Ontong Java and may have been constructed from the same broad plume source. Hypothesis and figure after Tarduno et al. (1991).

a single component of magnetization after the removal of a spurious remanence having low unblocking temperatures $\left(<150^{\circ} \mathrm{C}\right)$. Magnetic susceptibility decreases slightly $(\sim 30 \%)$ with increasing thermal demagnetization temperature. Maximum unblocking temperatures range from $400^{\circ} \mathrm{C}$ (Figs. $2 \mathrm{~A}-\mathrm{B}$ ) to $580^{\circ} \mathrm{C}$ (Figs. 2C-D). Although this range of maximum unblocking temperatures could arise from grainsize variations, it might instead reflect a composition range from relatively high-Ti titanomagnetite content to end-member magnetite. In Category B (Fig. 3), a distinct overprint is removed at low unblocking temperatures. The overprints include shallow inclination (B.1) directions (Fig. 3A) that are consistent with a viscous remanent magnetization (VRM) in the present-day field as the site is situated near the equator. Such present-day field overprints, however, are not common enough or sufficiently well defined (even with $25^{\circ} \mathrm{C}$ or 2.5-mT alternating-field (AF) demagnetization increments) to serve as a mechanism for azimuthal orientation. Steep inclination (B.2) overprints (Fig. 3B) are also observed but are relatively rare. Such steep components might be induced by the drill string, a common type of overprint that has plagued many paleomagnetic studies of DSDP and ODP cores. Occasionally the overprint is only revealed by the curved trajectory of the demagnetization path (B.3) (Fig. 3C). In Category C (Fig. 4), a reversal of the remanence is seen at a discrete unblocking temperature range, between $250^{\circ}$ and $350^{\circ} \mathrm{C}$. This phenomenon is seen in only a few samples. In the samples that display this behavior, the intensity of the reversed component varies substantially. Accompanying the apparent reversal of remanence is a distinct sequence of changes in magnetic susceptibility (Fig. 5). Susceptibility first decreases between $200^{\circ}$ and $300^{\circ} \mathrm{C}$, and then it rises between $300^{\circ}$ and $400^{\circ} \mathrm{C}$. Finally, susceptibility decreases at higher unblocking temperatures $\left(500^{\circ}-600^{\circ} \mathrm{C}\right)$. No one-to-one correlation, however, exists between this behavior and the reversal of remanence. Although all samples that display the reversal of remanence show the sequential $K$ changes detailed above, other samples show similar $K$ changes without the reversal of remanence.

Detailed stepwise AF demagnetization was also applied to 29 samples (Fig. 6). A similar paleomagnetic directional content to that noted during thermal demagnetization was observed with two exceptions. First, the apparent reversal of remanence during demagnetization (Type C) was not observed. If the reversal of remanence were a field direction, we should expect to see it in the AF data and in other unblocking temperature ranges during thermal demagnetization. Therefore, based on the discrete unblocking temperature range of the reversed component, its nearly antiparallel character in each sample, its lack of definition in AF data, and, when observed, its coincidence with $K$ changes, we suggest that the component is a manifestation of alteration-induced self-reversal. Further characterization of this artifact is beyond the scope of the present study.

The other difference between the thermal and AF data is the tendency of directions to deviate slightly from the origin of orthogonal vector plots, indicating the presence of an unresolved, high-coercivity mineral. This behavior, however, was noted in only a few samples and should not significantly bias the data set. Susceptibility 
Table 1. Paleomagnetic data for Hole $807 \mathrm{C}$ basalts.

\begin{tabular}{|c|c|c|c|c|c|c|c|c|c|}
\hline $\begin{array}{l}\text { Core, section, } \\
\text { interval }(\mathrm{cm})\end{array}$ & $\begin{array}{l}\text { Depth } \\
\text { (mbsf) }\end{array}$ & ChRM range & $n$ & $\alpha_{\text {ChRM }}$ & $D^{\circ}$ & $l^{\circ}$ & $K_{0.47 k H z}$ & $K_{0.47 k H z}$ & $Q$ \\
\hline \multicolumn{10}{|l|}{$130-807 \mathrm{C}-$} \\
\hline${ }^{2} 74 \mathrm{R}-3,124-126$ & 1379.64 & $20.0-80.0+0$ & 14 & 1.0 & 131.9 & -40.3 & 2760 & 2640 & 24.0 \\
\hline $74 \mathrm{R}-3,133-135$ & 1379.73 & $75.0-500.0+0$ & 12 & 1.4 & 126.7 & -42.0 & 2773 & 2608 & 18.3 \\
\hline $74 R-4,14-16$ & 1379.94 & $20.0-80.0+0$ & 14 & 1.9 & 83.1 & 4 r. 8 & 2844 & 2718 & 10.2 \\
\hline $74 \mathrm{R}-4,131-133$ & 1381.11 & $300.0-580.0+0$ & 9 & 0.7 & 18.0 & -44.5 & 1838 & 1776 & 76.4 \\
\hline $74 R-5,7-9$ & 1381.17 & $7.5-80.0+0$ & 18 & 0.5 & 112.0 & -41.2 & 2514 & 2417 & 28.8 \\
\hline $74 \mathrm{R}-5,39-41$ & 1381.49 & $300.0-580.0+0$ & 9 & 2.0 & 320.6 & -44.9 & 2565 & 2445 & 20.2 \\
\hline "78R-1, 76-78 & 1410.26 & $5.0-80.0+0$ & 13 & 1.0 & 69.2 & -40.2 & 2468 & 2358 & 21.1 \\
\hline $78 R-1,86-88$ & 1410.36 & $300.0-500.0+0$ & 6 & 4.1 & 68.0 & -43.1 & 2652 & 2493 & 15.3 \\
\hline${ }^{2} 78 \mathrm{R}-2,7-9$ & 1410.92 & $10.0-80.0+0$ & 15 & 0.8 & 53.0 & -40.8 & 2492 & 2391 & 22.7 \\
\hline $78 \mathrm{R}-2,12-14$ & 1410.97 & $150.0-580.0+0$ & 12 & 0.9 & 50.1 & -41.1 & 2473 & 2337 & 25.1 \\
\hline${ }^{2} 78 R-2,50-52$ & 1411.35 & $10.0-80.0+0$ & 11 & 0.9 & 324.7 & -43.0 & 2755 & 2610 & 9.5 \\
\hline $78 R-2,125-127$ & 1412.10 & $125.0-500.0+0$ & 10 & 1.4 & 344.8 & -41.9 & 2753 & 2601 & 20.8 \\
\hline${ }^{2} 80 \mathrm{R}-2,119-121$ & 1426.57 & $15.0-80.0$ & 12 & 2.6 & 279.6 & -28.6 & 1997 & 2001 & 4.1 \\
\hline${ }^{2} 80 \mathrm{R}-2,130-132$ & 1426.68 & $15.0-80.0+0$ & 9 & 2.3 & 283.1 & -39.7 & 3032 & 3039 & 4.5 \\
\hline${ }^{2} 80 \mathrm{R}-3,43-45$ & 1427.27 & $7.5-80.0+0$ & 12 & 2.0 & 12.5 & -27.7 & 2555 & 2558 & 3.2 \\
\hline${ }^{2} 80 \mathrm{R}-3,53-55$ & 1427.37 & $12.5-80.0$ & 9 & 1.8 & 89.2 & -31.3 & 2426 & 2431 & 3.6 \\
\hline${ }^{2} 80 \mathrm{R}-4,31-33$ & 1428.63 & $20.0-40.0+0$ & 4 & 1.2 & 290.2 & -35.6 & 2094 & 2099 & 2.0 \\
\hline${ }^{2} 80 \mathrm{R}-4,53-55$ & 1428.85 & $30.0-99.9$ & 16 & 2.4 & 76.4 & -30.7 & 2287 & 2299 & 11.1 \\
\hline $83 R-2,40-42$ & 1448.51 & $300.0-550.0+0$ & 8 & 1.4 & 267.7 & -41.1 & 3606 & 3522 & 6.0 \\
\hline${ }^{2} 83 R-3,51-53$ & 1450.12 & $5.0-80.0+0$ & 13 & 1.8 & 93.4 & -43.0 & 3458 & 3421 & 4.1 \\
\hline $83 R-4,31-33$ & 1451.04 & $300.0-580.0+0$ & 9 & 4.9 & 284.2 & -40.1 & 4197 & 4079 & 2.7 \\
\hline 283R-5, 3-5 & 1452.27 & $10.0-80.0+0$ & 16 & 2.4 & 50.0 & -29.8 & 3803 & 3746 & I5.1 \\
\hline $83 R-6,52-54$ & 1454.29 & $200.0-580.0+0$ & 11 & 1.1 & 102.8 & -30.7 & 3220 & 3155 & 9.1 \\
\hline${ }^{2} 83 R-7,59-61$ & 1455.40 & $12.5-80.0+0$ & 10 & 1.0 & 331.8 & -29.4 & 3110 & 3081 & 11.1 \\
\hline $85 R-1,9-11$ & 1465.69 & $75.0-500.0+0$ & 12 & 2.8 & 110.3 & -36.9 & 3530 & 3486 & 6.5 \\
\hline${ }^{2} 85 R-2,118-120$ & 1467.68 & $7.5-80.0+0$ & 12 & 3.1 & 272.4 & -41.1 & 3651 & 3629 & 2.2 \\
\hline $85 R-3,118-120$ & 1469.13 & $400.0-550.0+0$ & 6 & 3.8 & 77.0 & -24.9 & 4646 & 4536 & 1.2 \\
\hline $85 R-4,84-86$ & 1470.19 & $350.0-525.0+0$ & 6 & 4.1 & 171.5 & -31.9 & 4419 & 4332 & 1.7 \\
\hline "285R-5, 100-102 & 1471.83 & $7.5-80.0+0$ & 12 & 1.9 & 52.8 & -26.3 & 4368 & 4308 & 1.9 \\
\hline $85 R-7.52-54$ & 1473.87 & $200.0-450.0+0$ & 7 & 2.1 & 297.8 & -11.8 & 3547 & 3432 & 4.3 \\
\hline $86 R-2,50-52$ & 1477.14 & $15.0-80.0+0$ & 15 & 1.8 & 25.2 & -48.0 & 2623 & 2659 & 12.3 \\
\hline $86 R-2,58-60$ & 1477.22 & $450.0-580.0+0$ & 5 & 1.8 & 194.7 & -53.1 & 2071 & 2075 & 14.1 \\
\hline $86 \mathrm{R}-2,127-129$ & 1477.91 & $300.0-525.0+0$ & 7 & 2.7 & 178.6 & -52.9 & 2837 & 2840 & 2.8 \\
\hline $86 \mathrm{R}-3,43-45$ & 1478.47 & $310.0-580.0+0$ & 7 & 1.6 & 234.9 & -46.0 & 3419 & 3430 & 5.3 \\
\hline "286R-3, 72-74 & 1478.76 & $20.0-80.0+0$ & 14 & 2.4 & 326.0 & -39.8 & 3705 & 3678 & 4.2 \\
\hline $86 R-4,11-13$ & 1479.57 & $310.0-580.0+0$ & 7 & 1.0 & 159.9 & -44.7 & 2601 & 2603 & 4.2 \\
\hline $87 R-1,106-108$ & 1486.06 & $150.0-550.0+0$ & II & 2.1 & 40.7 & -33.1 & 3141 & 3148 & 5.1 \\
\hline $87 R-1.111-113$ & 1486.11 & $310.0-580.0+0$ & 6 & 2.2 & 44.6 & -26.9 & 3456 & 3463 & 7.2 \\
\hline "87R-1, $118-120$ & 1486.18 & $7.5-80.0+0$ & 19 & 0.9 & 229.9 & -37.3 & 3012 & 3001 & 4.9 \\
\hline $87 R-2,42-44$ & 1486.68 & $150.0-550.0+0$ & II & 1.1 & 3.0 & -29.5 & 2452 & 2459 & 5.3 \\
\hline $87 R-2,47-49$ & 1486.73 & $310.0-580.0+0$ & 7 & 1.7 & 5.5 & -29.5 & 2771 & 2789 & 4.3 \\
\hline $87 R-3,17-19$ & 1487.93 & $310.0-580.0+0$ & 7 & 0.5 & 344.7 & -34.0 & 2044 & 2049 & 6.1 \\
\hline a $88 R-2,26-28$ & 1496.07 & $20.0-80.0+0$ & 14 & 1.2 & 317.2 & -31.9 & 3539 & 3517 & 3.6 \\
\hline $88 R-2,41-43$ & 1496.22 & $350.0-580.0+0$ & 8 & 0.8 & 308.1 & -26.7 & 3094 & 3102 & 4.1 \\
\hline a $88 \mathrm{R}-3,31-33$ & 1497.62 & $7.5-55.0+0$ & 13 & 1.1 & 181.4 & -28.1 & 2732 & 3722 & 3.6 \\
\hline $88 R-3,55-57$ & 1497.86 & $210.0-580.0+0$ & 8 & 2.8 & 67.7 & -26.6 & 2691 & 2701 & 4.7 \\
\hline $88 \mathrm{R}-4.29-31$ & 1498.83 & $300.0-580.0+0$ & 9 & 1.1 & 336.4 & -21.5 & 3025 & 3035 & 5.8 \\
\hline $88 R-4,48-50$ & 1499.02 & $110.5-580.0+0$ & 9 & 0.9 & 351.2 & -22.6 & 2231 & 2240 & 6.9 \\
\hline a $89 \mathrm{R}-1,84-86$ & 1503.84 & $7.5-80.0+0$ & 18 & 0.5 & 192.6 & -23.7 & 3132 & 3101 & 12.1 \\
\hline $89 \mathrm{R}-1,103-105$ & 1504.03 & $310.0-580.0+0$ & 7 & 1.3 & 24.4 & -25.0 & 3877 & 3838 & 5.2 \\
\hline $89 R-2,43-45$ & 1504.93 & $350.0-580.0+0$ & 8 & 1.2 & 281.3 & -32.0 & 3237 & 3222 & 3.4 \\
\hline $89 R-2,73-75$ & 1505.23 & $310.0-580.0+0$ & 7 & 0.8 & 213.1 & -31.0 & 3688 & 3681 & 3.9 \\
\hline a $89 R-2,123-125$ & 1505.73 & $20.0-80.0+0$ & 14 & 2.2 & 102.3 & -28.0 & 3637 & 3611 & 5.3 \\
\hline $89 \mathrm{R}-3,36-38$ & 1506.36 & $310.0-580,0+0$ & 7 & 2.6 & 294.4 & -25.9 & 3796 & 3778 & 4.3 \\
\hline $90 \mathrm{R}-1,48-50$ & 1509.58 & $300.0-400.0+0$ & 4 & 3.6 & 83.9 & -27.7 & 3357 & 3320 & 4.8 \\
\hline $90 R-1,62-64$ & 1509.72 & $310.0-500.0+0$ & 5 & 5.0 & 78.8 & -33.6 & 3466 & 3362 & 5.0 \\
\hline a90R-1. 85-87 & 1509.95 & $12.5-80.0+0$ & 16 & 2.3 & 84.3 & -30.4 & 3246 & 2227 & 6.9 \\
\hline $90 \mathrm{R}-1,111-113$ & 1510.21 & $310.0-500.0+0$ & 5 & 4.2 & 81.0 & -32.6 & 3515 & 3411 & 5.5 \\
\hline $90 R-2,104-106$ & 1511.64 & $400.0-580.0+0$ & 7 & 1.4 & 242.1 & -34.2 & 3131 & 3134 & 5.6 \\
\hline $90 \mathrm{R}-3,138-140$ & 1513.28 & $350.0-580.0+0$ & 8 & 1.5 & 195.0 & -29.2 & 3730 & 3724 & 6.2 \\
\hline 9|R-1.39-4I & 1515.69 & $310.0-580.0+0$ & 7 & 2.3 & 202.1 & -24.4 & 3857 & 3731 & 3.1 \\
\hline $91 \mathrm{R}-1,48-50$ & 1515.78 & $20.0-80.0+0$ & 14 & 9.9 & 201.4 & -27.7 & 3573 & 3539 & 1.9 \\
\hline $91 R-1,53-55$ & 1515.82 & $350.0-580.0+0$ & 8 & 9.5 & 206.3 & -17.0 & 3933 & 3817 & 1.6 \\
\hline $92 \mathrm{R}-1,25-27$ & 1517.05 & $10.0-80.0+0$ & 17 & 1.3 & 331.9 & -18.1 & 3637 & 3630 & 5.4 \\
\hline $92 \mathrm{R}-1,51-53$ & 1517.31 & $310.0-580.0+0$ & 7 & 1.2 & 360.0 & -21.7 & 3625 & 3554 & 6.2 \\
\hline $92 \mathrm{R}-1,95-97$ & 1517.75 & $200.0-680.0+0$ & 15 & 1.5 & 6.0 & -30.8 & 3231 & 3161 & 6.3 \\
\hline $92 \mathrm{R}-1,113-115$ & 1517.93 & $410.0-580.0+0$ & 6 & 1.2 & 3.0 & -34.3 & 2488 & 2469 & 2.6 \\
\hline $92 \mathrm{R}-2,74-76$ & 1518.76 & $12.5-80.0+0$ & 16 & 1.2 & 36.1 & -21.9 & 3688 & 3680 & 5.5 \\
\hline $92 \mathrm{R}-2,84-86$ & 1518.86 & $150.0-500.0+0$ & 9 & 0.9 & 348.9 & -21.1 & 3582 & 3544 & 3.4 \\
\hline $93 R-2,3-5$ & 1520.22 & $410.0-580.0+0$ & 6 & 2.6 & 35.6 & -12.5 & 2786 & 2735 & 5.1 \\
\hline $93 R-2,12-14$ & 1520.31 & $410.0-580.0+0$ & 6 & 1.1 & 60.7 & -15.0 & 2371 & 2333 & 9.5 \\
\hline${ }^{\mathrm{a}} 93 \mathrm{R}-2,91-93$ & 1521.10 & $25.0-80.0+0$ & 13 & 2.3 & 262.4 & -21.8 & 3902 & 3877 & 6.0 \\
\hline $93 R-2,98-100$ & 1521.17 & $410.0-550.0+0$ & 5 & 0.9 & 302.9 & -19.8 & 3872 & 3817 & 6.9 \\
\hline $93 R-2,109-111$ & 1521.28 & $400.0-525.0+0$ & 5 & 8.1 & 304.7 & -13.0 & 3415 & 3362 & 7.2 \\
\hline $93 R-3,35-37$ & 1521.90 & $410.0-580.0+0$ & 6 & 3.0 & 267.0 & -28.3 & 3218 & 3142 & 1.3 \\
\hline
\end{tabular}

Notes: ChRM range $=$ temperature or peak alternating-field range from which the characteristic remanent magnetization (ChRM) was determined, temperatures in " $\mathrm{C}$, peak alternating field in $\mathrm{mT}$. " $+\mathrm{O}$ " signifies that the origin was used in the ChRM fit: $n=$ number of points used in ChRM determination; $\alpha C h R M=$ mean angular deviation of least squares fit of ChRM: $D^{\circ}=$ ChRM declination in degrees: $l^{\circ}=$ ChRM inclination in degrees; $K_{0,7} k H z=$ low-frequency volume magnetic susceptibility $\times 10^{-5} \mathrm{SI}$ units (dimensionless); $K_{4,7} \mathrm{kHz}=$ high-frequency volume magnetic susceptibility $\times 10^{-5}$ in SL units (dimensionless): $Q=$ Koenigsberger ratio.

a Sample treated by alternating-field demagnetization (otherwise treated by thermal demagnetization).

' Sample interpreted as accidentally inverted. For samples treated by alternating field, $K$ and $Q$ values were derived from measurements after demagnetization; for sample treated thermally, $K$ and $Q$ values were derived from measurements before heating. 
A

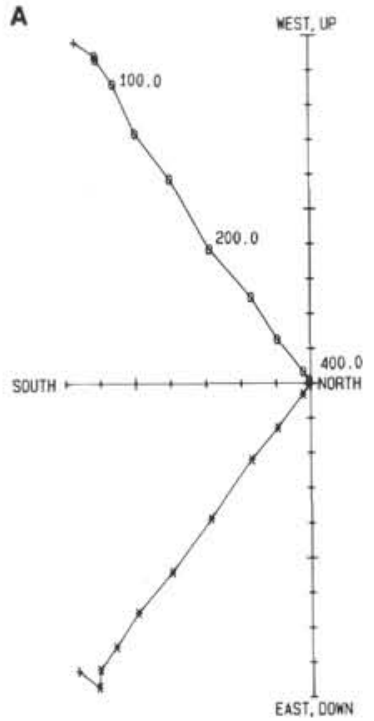

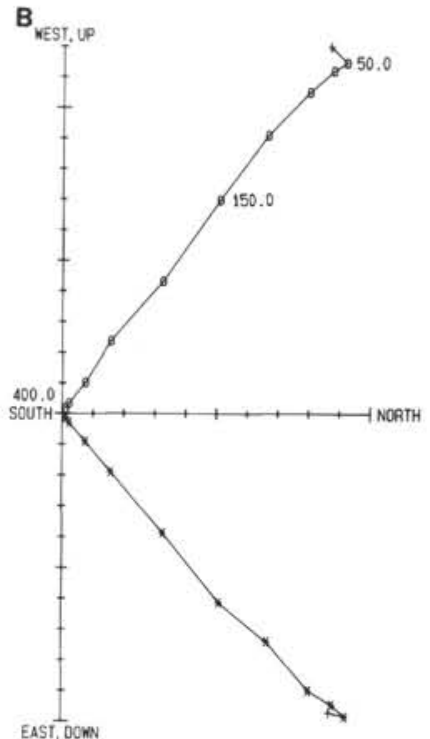

D

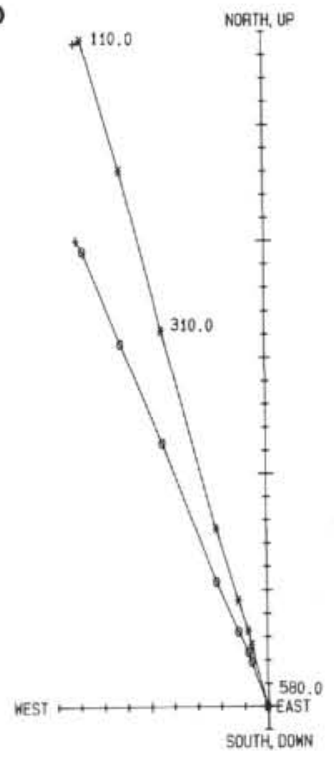

C,

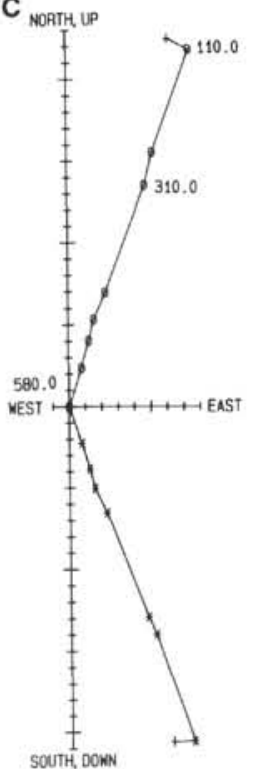

A

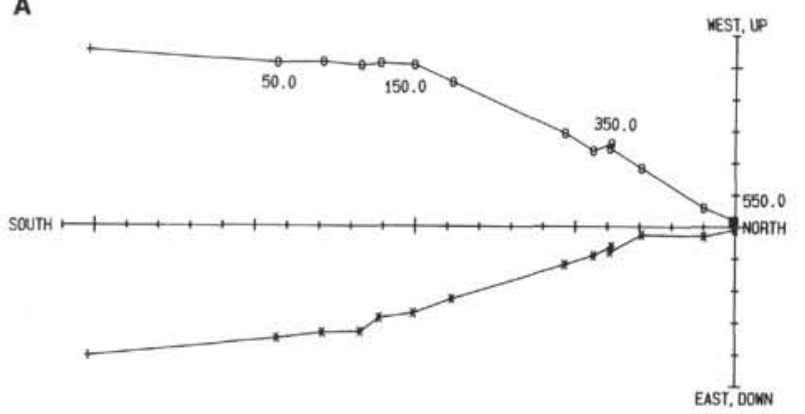

B

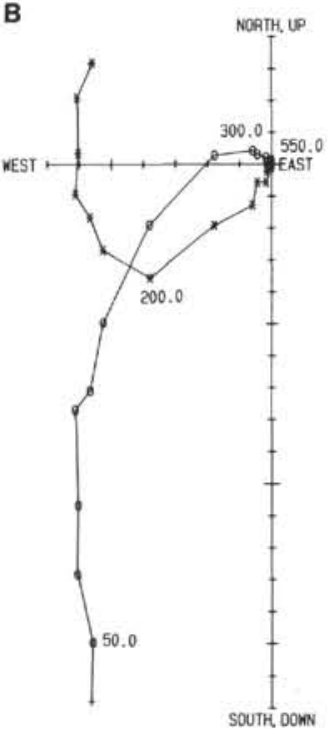

Figure 2. Orthogonal vector plots of progressive thermal demagnetization of natural remanent magnetization. Circles $=$ inclination, asterisks $=$ declination. A. Sample 130-807C-74R-3, 133-135 cm; ticks plotted every $1.0 \times 10^{-2} \mathrm{emu}$; demagnetization steps (in degrees Celsius) shown: 0, 50, 75, 100, 125, 150, $200,250,300,350$, and 400. B. Sample 130-807C-78R-2, 12-14 cm; ticks plotted every $1.0 \times 10^{-2} \mathrm{emu}$; demagnetization steps (in degrees Celsius) shown: $0,50,75,100,125,150,200,250,300,350$, and 400. C. Sample 130-807C-86R-4, 11-13 cm; ticks plotted every $1.0 \times 10^{-3} \mathrm{emu}$; demagnetization steps (in degrees Celsius) shown: $0,110,210,310,410,450,500,550$, and 580. D. Sample 130-807C-87R-3, 17-19 cm; ticks plotted every $1.0 \times 10^{-3}$ $\mathrm{emu}$; demagnetization steps (in degrees Celsius) shown: 0, 110, 210,310,410, $450,500,550$, and 580 . Maximum unblocking temperatures vary throughout the basalt section; Samples 130-807C-74R-3, 133-135 cm, and -78R-2, 12-13 $\mathrm{cm}$ (Figs. 2A and 2B), have maximum unblocking temperatures of $400^{\circ} \mathrm{C}$ whereas Samples 130-807C-86R-4, 11-13 cm, and -87R-3, 17-19 cm (Figs. $2 \mathrm{C}$ and $2 \mathrm{D}$ ), have maximum unblocking temperatures of $580^{\circ} \mathrm{C}$. All samples display single-component behavior after the removal of a small, spurious component at low unblocking temperatures $\left(<110^{\circ} \mathrm{C}\right)$. 



Figure 4. Orthogonal vector plots of progressive thermal demagnetization of natural remanent magnetization. Circles $=$ inclination, asterisks $=$ declination. $\mathbf{A}$. Sample 130-807C-87R-2, 42-44 cm; ticks plotted every $1.0 \times 10^{-3}$ emu; demagnetization steps (in degrees Celsius) shown: $0,50,75,100,125,150,200,250$, $300,350,400,450,500,525$, and 550. B. Sample 130-807C-88R-2, 41-43 cm; ticks plotted every $1.0 \times 10^{-3}$ emu; demagnetization steps (in degrees Celsius) shown: $0,50,75,100,125,150,200,250,300,350,400,450,500,525,550$, and 580 . C. Sample 130-807C-89R-2, $43-45 \mathrm{~cm}$; ticks plotted every $1.0 \times 10^{-3}$ emu; demagnetization steps (in degrees Celsius) shown: $0,50,75,100,125,150,200,250,300,350,400,450,500,525,550$, and 580. D. Sample 130-807C-90R-3, $138-140 \mathrm{~cm}$; ticks plotted every $1.0 \times 10^{-3} \mathrm{emu}$; demagnetization steps (in degrees Celsius) shown: $0,50,75,100,125,150,200,250,300,350,400,450,500$, 525,550 , and 580 .

measurements taken after AF demagnetizations do not differ greatly from values before demagnetization and, like values from samples not treated by AF demagnetization, hint at a slight frequency dependence. The characteristic remanent magnetization (ChRM) directions, $K$, and $Q$ values vs. depth are summarized in Table 1 and Figure 7 . One sample (130-807C-74R-4, 14-16 cm) having Type-Ademagnetization behavior is inferred to have been accidentally inverted during recovery or sampling.

To further evaluate the possibility that overprints have been inadequately removed during demagnetization, we compare the results from thermal demagnetization $\left(I^{\prime}=-32.5_{-2.0}^{\circ+3.0}\right.$, maximum likelihood estimate of mean inclination, $I^{\prime}$, after McFadden and Reid, 1982) and AF demagnetization $\left(I^{\prime}=-33.7_{-3.1}^{\circ+3.8}\right)$. The means are statistically indistinguishable at the $95 \%$ confidence level, giving us further confidence in the effectiveness of the demagnetization procedures applied. We note that the inclination data are dominated by Type-A demagnetization behavior. Only four samples (130-807C-80R-4, 31$33 \mathrm{~cm}$; $-85 \mathrm{R}-3,118-120 \mathrm{~cm}$; $-91 \mathrm{R}-1,48-50 \mathrm{~cm}$; $-91 \mathrm{R}-1,53-55 \mathrm{~cm}$ ) show a large overprint during demagnetization (Type B.2). Samples having an overprint manifested only by a curved demagnetization path (Type B.3) can potentially bias the inclination data toward shallow values. From a comparison of curvature apparent in the demagnetization paths and the final ChRM column (Fig. 7), we find only one sample, within Subunit F, in which a B.3-type overprint may have resulted in an inclination bias toward shallow values: $130-807 \mathrm{C}$ 85R-7, 52-54 cm (Fig. 3).

\section{INCLINATION GROUPS}

To obtain an estimate of paleolatitude, the individual ChRM inclinations (Table 1) must be combined into distinct magnetic units. Following the method of Kono (1980), we calculate the statistic Z: 


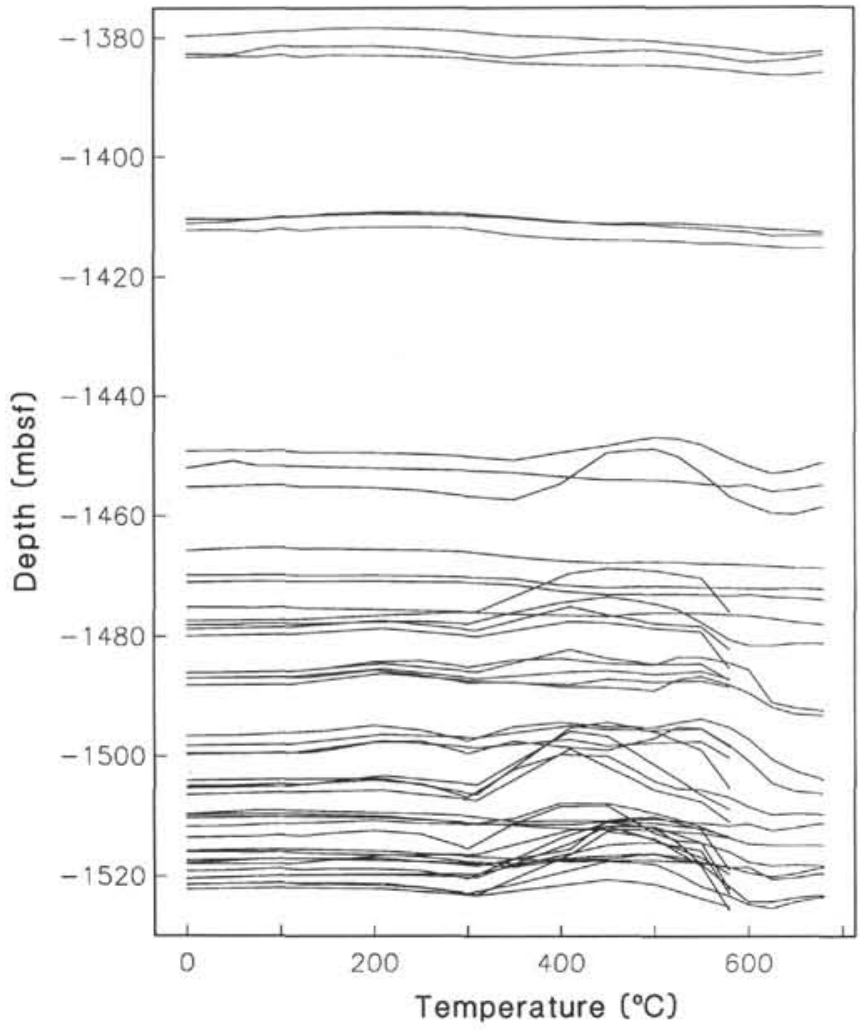

Figure 5. Change of low field volume susceptibility $(0.47 \mathrm{kHz})$ vs. thermal demagnetization temperature for basalt samples from Hole 807C. Each susceptibility profile is normalized to the NRM susceptibility. Some levels show only small changes in susceptibility with thermal treatment (e.g., 1380-1420 mbsf), whereas others show a decrease between $200^{\circ}$ and $300^{\circ} \mathrm{C}$, followed by a rise between $300^{\circ}$ and $400^{\circ} \mathrm{C}$, in turn followed by a drop at higher temperatures $\left(500^{\circ}-600^{\circ} \mathrm{C}\right)$. The maximum change is $1.6 \times$

$$
Z=\frac{\bar{I}_{1}-\bar{I}_{2}}{\sqrt{\frac{\sigma_{1}^{2}}{n_{1}}-\frac{\sigma_{2}^{2}}{n_{2}}}},
$$

where $\bar{I}_{1}$ and $\bar{I}_{2}$ are the means of two adjacent inclination groups, $\sigma_{1}$ and $\sigma_{2}$ are their standard deviations, and $n_{1}$ and $n_{2}$ equal the number of points used in each inclination group. The data are divided such that the inclination groups differ at the $95 \%$ confidence level $(Z>$ 1.96). Using this criterion, the Hole $807 \mathrm{C}$ sequence can be divided into 14 magnetic units (Table 2). One surprising result of this analysis is that the flood basalt, Subunit F, can be divided into 4 magnetic groups, in contradiction with its fast predicted cooling history.

If the flow was deposited instantaneously and a significant amount of secular variation was present during its cooling, we should expect to see symmetry in paleomagnetic inclination about a line within the flow where the two cooling fronts (one propagating downward from the top and the other propagating upward from the bottom) met. The line of symmetry should be closer to the base of the flow as the upper surface likely had a greater component of cooling because of convection. In the available data, however, no symmetry is apparent. In practice, the assumption that the flow was deposited instantaneously is likely a poor one. To form underwater, a pillow carapace must first have formed with the final flow forming by magma inflation. Therefore, the cooling history within the flow may have been complex.

To address uncertainties presented by multiple apparent inclination groups with the flood basalt, we calculate mean inclination values with and without Subunit F. Averaging values within the inclination

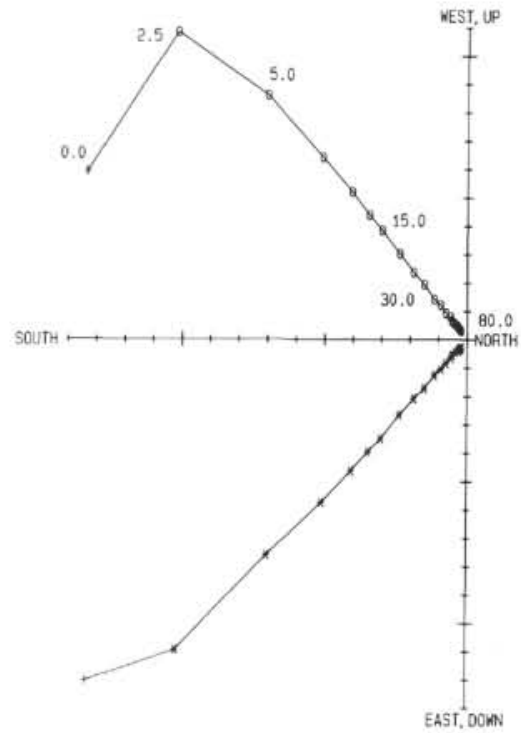

Figure 6. Orthogonal vector plot of progressive AF demagnetization of natural remanent magnetization. Circles $=$ inclination, asterisks $=$ declination. Sample 130-807C-74R-3, 124-126 cm; ticks plotted every $1.0 \times 10^{-2} \mathrm{emu}$; demagnetization steps (in $\mathrm{mT}$ ) shown: $0,2.5,5.0,7.5,10.0,12.5,15.0,20.0,25.0,30.0$, $35.0,40.0,45.0,50.0,55.0,60.0,65.0,70.0,75.0$, and 80.0 .

groups and between groups using the method of McFadden and Reid (1982) yields an average inclination of $-33.2^{\circ}$ (Tables 2 and 3) with Subunit $\mathrm{F}$ and $-32.3^{\circ}$ without Subunit F.

Using the $125-\mathrm{Ma}$ pole for the Pacific APWP $\left(51.4^{\circ} \mathrm{N}, 323.1^{\circ} \mathrm{E}\right)$ (Gordon, 1990), an inclination of $-53.9^{\circ}$ is predicted for Site 807 in Early Cretaceous times. The mean Site 807 inclination calculated above is $21^{\circ}$ shallower than this predicted inclination. Closer inspection of the Site $807 \mathrm{ChRM}$ inclination data, however, reveals a trend in the data from steeper values at the top of the sequence to shallower values at the base. Linear regression suggests a slope of $0.13 \% \mathrm{~m}(R$ $=0.62$ ). The observation of a shallower than expected inclination (as compared with the Pacific APWP; Gordon, 1990), the presence of a downhole trend in the inclinations toward greater shallowing with depth, and the graben structure at Site 807 are all consistent with tilting of the sequence during the waning phases of volcanism. Therefore, the ChRM inclinations cannot be taken at face value as indicators of paleolatitude.

\section{DISCUSSION}

Because hotspot-based plate reconstructions (R.G. Gordon and L.J. Henderson, unpubl. data, 1991; Duncan and Clague, 1985) place the Ontong Java Plateau at $51^{\circ} \mathrm{S}$ on the Louisville hotspot (e.g., Lonsdale, 1988) in Early Cretaceous times, paleomagnetic estimates of the paleolatitude of Site 807 can place constraints on the relative motion between the hotspot reference frame and the spin axis, termed true polar wander (TPW). Because the paleomagnetic data from Site 807 themselves are likely affected by tilting, we must rely on other data to estimate such a paleolatitude. Potential systematic errors is such data must also be discussed.

Gordon (1990) has recently constructed an APWP for the Pacific Plate based on nonsedimentary data sources: DSDP basalt colatitudes, marine magnetic anomaly skewness, and seamount paleopoles. Gordon (1990) then used this APWP to predict paleolatitudes for DSDP sites with paleolatitude estimates derived from the paleomagnetic analysis of sediments. When the two data sets were compared, a systematic bias in the sediment-derived data was observed toward shallow values. 


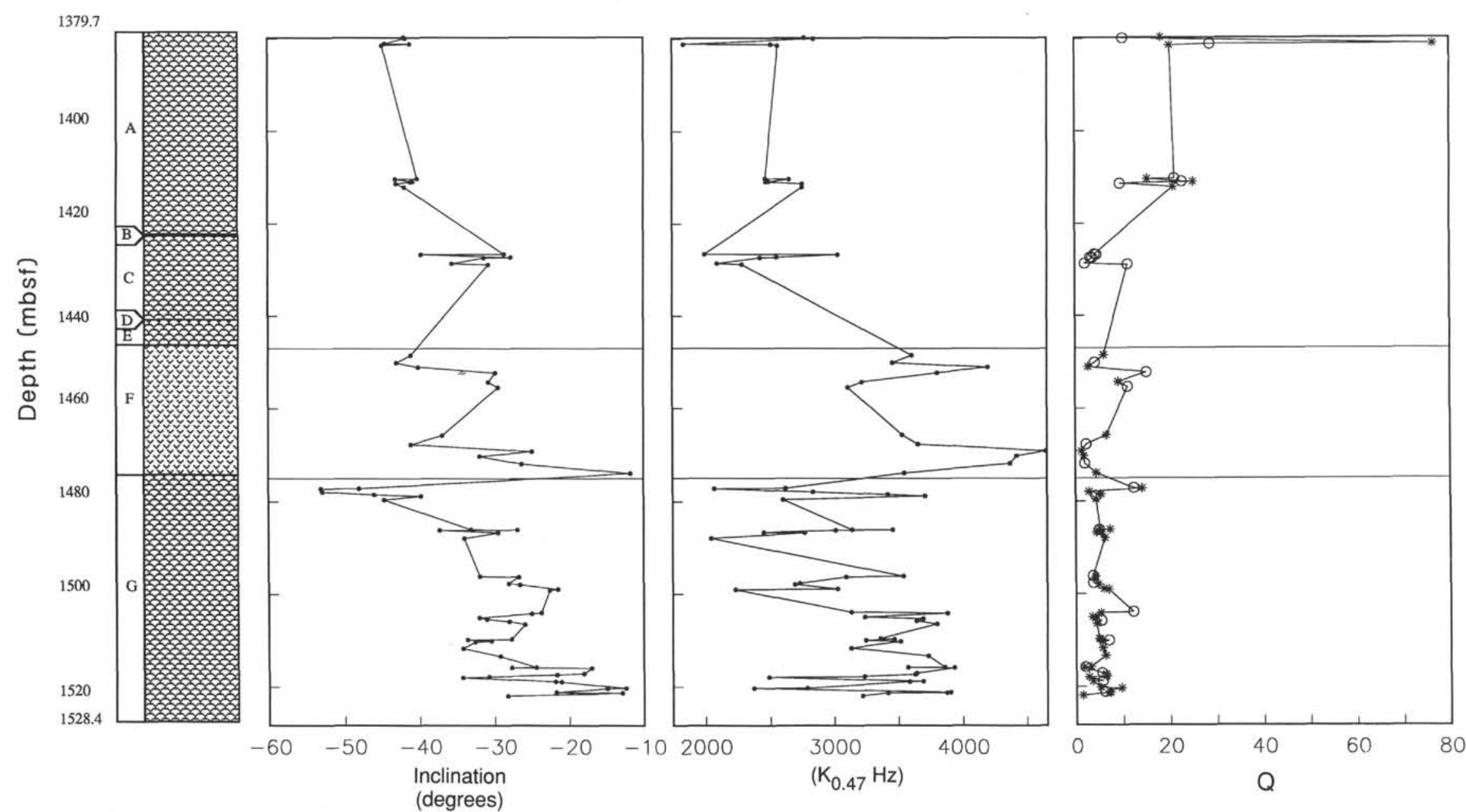

Figure 7. Subunits of the igneous complex, Hole $807 \mathrm{C}$, are shown vs. ChRM inclination, low-field volume susceptibility $(K)$, and Koenigsberger ratio $(Q)$ (see Table 1$)$. For thermal samples, $K$ was measured before demagnetization (asterisks). Horizontal lines on inclination, $K$, and $Q$ plots mark boundaries of the flood-basalt flow, Subunit F. In plot of $Q$, asterisks represent samples measured by thermal demagnetization, and open circles represent samples measured by alternating-field demagnetization. 
Table 2. Basalt inclination groups, Hole 807C.

\begin{tabular}{|c|c|c|c|c|c|c|c|}
\hline I Group & $\begin{array}{l}\text { Top } \\
\text { (mbsf) }\end{array}$ & $\begin{array}{c}\text { Base } \\
\text { (mbsf) }\end{array}$ & $n$ & $I$ & $I^{\prime}$ & k & $I_{95}$ \\
\hline 1 & 1379.64 & 1412.10 & 12 & -42.1 & -42.1 & 1394.7 & 1.1 \\
\hline 2 & 1426.57 & 1428.85 & 6 & -32.3 & -32.4 & 157.8 & 5.9 \\
\hline 3 & 1448.51 & 1451.04 & 3 & -41.4 & -41.4 & 1513.1 & 5.3 \\
\hline 4 & 1452.27 & 1455.40 & 3 & -30.0 & -30.0 & 7410.4 & 2.4 \\
\hline 5 & 1465.69 & 1467.68 & 2 & -39.0 & & & \\
\hline 6 & 1469.13 & 1473.87 & 4 & -23.7 & -24.0 & 45.5 & 17.9 \\
\hline 7 & 1477.14 & 1477.91 & 3 & -51.3 & -51.4 & 393.3 & 10.4 \\
\hline 8 & 1478.47 & 1479.57 & 3 & -43.5 & -43.6 & 307.0 & 11.7 \\
\hline 9 & 1486.06 & 1497.86 & 10 & -30.4 & -30.4 & 251.8 & 3.1 \\
\hline 10 & 1498.83 & 1504.03 & 4 & -23.2 & -23.2 & 1461.4 & 3.1 \\
\hline 11 & 1504.93 & 1515.78 & 12 & -29.7 & -29.8 & 344.0 & 2.3 \\
\hline 12 & 1515.82 & 1517.31 & 3 & -18.9 & -18.9 & 543.3 & 8.8 \\
\hline 13 & 1517.75 & 1517.93 & 2 & -32.6 & & & \\
\hline 14 & 1518.76 & 1521.90 & 8 & -19.2 & -19.3 & 114.0 & 5.4 \\
\hline
\end{tabular}

Notes: $n=$ number of points in each group; inclination-only statistics from McFadden and Reid (1982); $I=$ mean inclination; $l^{\prime}=$ maximum likelihood estimate of mean inclination; $\mathrm{k}=$ estimate of $\kappa ; I_{95}=95 \%$ confidence interval on mean inclination.

However, substantial sources of error are present in the nonsedimentary data. For example, analyses of marine magnetic anomaly skewness have identified the presence (but not the cause) of systematic errors (Petronotis and Gordon, 1989). Seamount paleopoles can be biased by VRM or induced magnetizations and, as highlighted by the Site 807 data, basalt colatitude can be affected by tilting.

Beside errors in the reference path, other explanations for the discrepancy between sedimentary and nonsedimentary results include unremoved VRMs on the sediments, differential tectonic motion within the Cretaceous "Pacific Plate," and compaction-induced inclination shallowing. Compaction-induced inclination shallowing is the best explanation for the anomaly as it explains why sites that reconstruct to positions farthest south in the Southern Hemisphere show the largest inclination anomaly whereas sites deposited close to the equator agree more closely with pole positions based on nonsedimentary data (see Tarduno, 1990). Although reference pole errors could enhance calculated flattening values in some age groups, an offset of the APWP cannot explain the latitude dependence of observed flattening values (Tarduno, 1990).

If the inclination values derived from Site 807 were not affected by tilting, the paleolatitude would agree more closely with sedimentary values from the region (e.g., Sites 288 and 167; see Tarduno, 1990). However, this would imply a greater degree of TPW since the early Cretaceous. For example, the Pacific APWP predicts a paleolatitude of $34^{\circ} \mathrm{S}$ for Ontong Java Plateau Site 807 during the Aptian. Cretaceous sites are concentrated in a "core" of the Pacific that was in the Southern Hemisphere, the Cretaceous Northern Hemisphere crust having been subducted in the Tertiary. Therefore, a direct relationship exists between inferred inclination shallowing and calculated TPW (given an equal spacing of sites in each hemisphere, the effects of inclination error on pole calculations cancel). For lesser amounts of inferred inclination shallowing, the calculated TPW is greater.

Therefore, given the available data, predicted paleolatitudes from the APWP of Gordon (1990) provide lower bounds on Pacific TPW since the early Cretaceous. In calculating such bounds another uncertainty must be addressed. Because the Ontong Java Plateau covers such a large area, the exact point matched to the Louisville hotspot latitude becomes an important consideration. To address this uncertainty, we calculate expected paleolatitudes for the southern (i.e., DSDP Site 288) and northern (i.e., ODP Site 807) portions of the Ontong Java Plateau. Based on these site locations, lower bounds on relative motion between the Louisville hotspot and the spin axis are $9^{\circ}-17^{\circ}$ to the south. These values are minimum motions because only the latitudinal component is considered.
Table 3. Average of inclination groups, Hole 807C.

\begin{tabular}{lccccc}
\hline \multicolumn{1}{c}{ Method } & $n$ & $I$ & $I^{\prime}$ & $\mathrm{k}$ & $I_{95}$ \\
\hline 1. $I^{\prime}$ Groups & 14 & -32.7 & -33.2 & 34.8 & 6.6 \\
2. $I^{\prime}$ Groups (excluding Subunit F) & 10 & -32.3 & -32.9 & 28.8 & 9.2 \\
\hline
\end{tabular}

Notes: Abbreviations as described in Table 2. Both averages use mean values for Groups 5 and 13. Method 2 excludes inclination Groups 3-6; see Table 2.

A similar calculation of Pacific TPW can be made for 65 Ma based on data from the Suiko Seamount (Kono, 1980). The Suiko Seamount is part of the Hawaiian-Emperor Chain emanating from the active Hawaiian hotspot $\left(19.5^{\circ} \mathrm{N}\right)$. Fortunately, a direct (untilted) measure of paleolatitude is available for the Suiko Seamount. Paleomagnetic analyses of flows drilled on Suiko (DSDP Site 433) indicate a paleolatitude of $27^{\circ} \mathrm{N}$; therefore, a minimum of $7.5^{\circ} \mathrm{S}$ of TPW is implied. Hence, the sense of motion estimated for the Ontong Java Plateau is consistent with that calculated from the Suiko Seamount.

\section{CONCLUSIONS}

Paleomagnetic data from Ontong Java Plateau Site 807 define a paleolatitude some $16^{\circ}$ shallower than values predicted from an APWP based on nonsedimentary data sets. The data also show a trend in inclination with shallower values downhole. We conclude that the inclination trend and apparent shallow paleolatitudes arise from local tectonic tilting during the waning phases of volcanism. Such tilting is a first-order uncertainty in any paleomagnetic results derived from deep-sea coring of basalt, especially in those sites with insufficient penetration to evaluate trends in the data. Review of the available Pacific Plate paleomagnetic data of Early Cretaceous age suggest lower bounds on TPW of $9^{\circ}-17^{\circ}$ to the south.

\section{ACKNOWLEDGMENTS}

We thank Yves Gallet, Jeff Gee, Catherine Johnson, and Dave Sandwell for helpful discussions. We acknowledge support for the paleomagnetic lab at Scripps Institution of Oceanography (SIO) from the Keck Foundation and the National Science Foundation. We are grateful to Gary Acton and Chuck Helsley for review of the manuscript and Lisa Tauxe and Jeff Gee for assistance in the SIO paleomagnetic laboratory. This research was supported by a grant from USSAC to J.A. Tarduno.

\section{REFERENCES*}

Andrews, J.E., Packham, G., et al., 1975. Init. Repts. DSDP, 30: Washington (U.S. Govt. Printing Office).

Duncan, R.A., and Clague, D.A. 1985. Pacific Plate motion recorded by linear volcanic chains. In Nairn, A.E.M., Stehli, F.G., and Uyeda, S. (Eds.), The Ocean Basins and Margins (Vol. 7A): New York (Plenum), 89-121.

Gordon, R.G., 1990. Test for bias in paleomagnetically determined paleolatitudes from Pacific Plate Deep Sea Drilling Project sediments. J. Geophys. Res., 95:8397-8404.

Harland, W.B., Armstrong, R.L., Cox, A.V., Craig, L.E., Smith, A.G., and Smith, D.G., 1990. A Geologic Time Scale 1989: New York (Cambridge Univ. Press).

Harland, W.B., Cox, A.V., Llewellyn, P.G., Pickton, C.A.G., Smith, A.G., and Walters, R., 1982. A Geologic Time Scale: New York (Cambridge Univ. Press).

Kono, M., 1980. Paleomagnetism of DSDP Leg 55 basalts and implications for the tectonics of the Pacific Plate. In Jackson, E.D., Koizumi, I., et al., Init. Repts. DSDP, 55: Washington (U.S. Govt. Printing Office) 737-752.

\footnotetext{
* Abbreviations for names of organizations and publication titles in ODP reference lists follow the style given in Chemical Abstracts Service Source Index (published by American Chemical Society).
} 
Kroenke, L.W., Berger, W.H., Janecek, T.R., et al., 1991. Proc. ODP, Init. Repts., 130: College Station, TX (Ocean Drilling Program).

Lonsdale, P., 1988. Geography and history of the Louisville hotspot chain in the southwest Pacific. J. Geophys. Res., 93:3078-3104.

McFadden, P.L., and Reid, A.B., 1982. Analysis of paleomagnetic inclination data. Geophys. J. R. Astron. Soc., 69:307-319.

Petronotis, K.E., and Gordon, R.G., 1989. Age dependence of skewness of magnetic anomalies above seafloor formed at the Pacific-Kula spreading center. Geophys. Res. Lett., 16:315-318.

Tarduno, J.A., 1990. Absolute inclination values from deep sea sediments: reexamination of the Cretaceous Pacific record. Geophys. Res. Lett., 17:101-104.
Tarduno, J.A., Sliter, W.V., Kroenke, L., Leckie, M., Mayer, H., Mahoney, J.J., Musgrave, R., Storey, M., and Winterer, E.L., 1991. Rapid formation of Ontong Java Plateau by Aptian mantle plume volcanism. Science, $18: 399-403$.

Date of initial receipt: 2 December 1991

Date of acceptance: 28 August 1992

Ms 130B-034 